\title{
The Position of Pancasila as Legal Ideals and Source of All Legal Sources in Indonesia
}

\author{
Fauzan Indra ${ }^{1}$, Azis Budianto ${ }^{2}$ \\ Student at Doctoral of Law, Universitas Borobudur Jakarta \\ \{fauzanunbor@gmail.com¹,azis_budianto@borobudur.ac.id²\}
}

\begin{abstract}
From the reformation era until now, Pancasila is just an idea that is often forgotten how its implementation in the life of the nation and state. As the foundation for the life of the nation and state, Pancasila has four positions, namely the state philosophy, ideology, legal ideals (rechtsidee), and the source of all sources of Indonesian law. The position of Pancasila as a legal ideal (rechtsidee) and the source of all sources of Indonesian law has not been fully utilized in the implementation of the formation of legislation. There are a lot of certain individuals who prostitute themselves for their personal and group interests by selling articles and verses that are indicated to be contrary to the ideals of Pancasila. Based on pragmatic political interests, the values of Pancasila are often ignored, which should be the source of all sources of law in Indonesia. Infiltration of the ideas of capitalism and liberalism often occurs in the process of forming legislation without heeding the interests of the people, nation, and state for the sole interest of investors, even for foreign interests. This condition is of course very worrying for all of us as the nation's children. This requires awareness of the ideals of Pancasila and make it as the source of all sources of law in Indonesia. As a rule of law, the ideals of Pancasila law must be placed as the basis and direction for the formation of legislation in Indonesia. Likewise, making Pancasila the source of all sources of law in Indonesia. With the stipulation of Pancasila as a fundamental norm (staatsfundamentalnorm), the formation of law, application, and implementation cannot be separated from the values of Pancasila.
\end{abstract}

Keywords: Pancasila; Legal Ideals; Source of All Legal Sources

\section{Introduction}

From the reformation 1998, Pancasila has suffered from decadency of its application or implementation in the life of nation and state. This condition is compounded by the development of various transnational ideology which marginalizing the great value of Pancasila. As a result, it's an impact on the ebbing of national values.

One of the deteriorations in the application of Pancasila is about the management of legislation formation that ignores Pancasila as a legal ideal and the source of all legal sources in Indonesia. It can be seen in the number of bills and laws that have been passed that must be corrected by judicial review to the Constitutional Court. It's because the contents of the articles and paragraphs in the Formulation of Laws or the Law itself is contradicting to the value of Pancasila, which creates a contradiction between an article to another or between 
regulation to another statutory. It is even worse the content of the articles that has been conveyed is tend to be capitalism and liberalism which is in contrast with Pancasila values as the foundation of national and state life.

According to Law Number 12 of 2011 concerning Establishment of Legislation, Article 2, is written that Pancasila is the source of all legal sources in Indonesia, which brings all the consequences of regulations sourced and should not conflict with the values of Pancasila. However, so far, there is an anomaly between the mandatory provision of Law Number 12 of 2011 and legislation practice in Indonesia.

On one side, there's said that Pancasila is the source of all legal sources, yet on another side, the legislators do not have implementation instructions and technical instructions that can be practiced when translating the principles of Pancasila into legal norms of all statutory regulations. This nation has been lost the reference values of Pancasila. As the result, from 2003 to 2017, there's about 244 lawsuits or examinations of the Constitution which is granted by the Constitutional Court because it's contrary to Pancasila and the 1945 Constitution of the Republic of Indonesia.

This condition has occurred since the Reformation era that currently there is not a single official state document that can be read about the values contained in the Pancasila principles that can be understood and be guided by Indonesia to recognize what and how the basic philosophy of the state contained in the principles of Pancasila according to the state's founders' intentions. Since there has been a historical distortion process so that we never knew the correct and objective authentical documents of the history of Pancasila.

At the beginning of the reform era, there had also been a misdiagnosis and a wrong political policy towards Pancasila. This mistake occurred when the reformist group at that time argued that Pancasila belonged to the New Order regime, so it must be eliminated again. As a result, MPR Decree Number II of 1978 concerning P4 was revoked, the BP7 institution was dissolved and the elimination of Pancasila subjects from the main subjects in schools and universities was also carried out.

As a result, the understanding of Pancasila values in the current reformation era seems to be left to the free market mechanism in which every individual, group, and free independent group interprets the meaning contained in the Pancasila principles according to their tastes and interests. It is very dangerous if everyone, groups, and groups interpret according to their own interests and ignore the interests of the larger nation.

In the long term, the absence of directions and guidelines for interpreting and understanding Pancasila according to the founders of Pancasila as the basis of the state can lead to disorientation and also to the disintegration of the nation. Therefore, to understand what is contained in the principles of Pancasila, this nation must return to the history of the formation of Pancasila, which began with Bung Karno's speech on June 1, 1945, which then developed into the text of the Jakarta Charter of 22 June 1945 by the Committee Nine until a national consensus is reached in the formulation of the final text on August 18, 1945.

We must interpret the whole process as a unified process of the birth of Pancasila as the basis of the state by the founders of the state. The historical aspects and historical origins must be known from generation to generation so that Pancasila remains sustainable. As the foundation for the life of the nation and state, Pancasila has four positions, namely the state philosophy, ideology, legal ideals (rechtsidee), and the source of all sources of Indonesian law. Pancasila as the state philosophy is derived from a source of value in the context of the dynamic journey of the nation's cultural history.

Pancasila is the basic ideology of the Indonesian nation, namely as the values that underlie all aspects of life in society, nation, and state. Pancasila consists of five main principles, 
namely: (1) God Almighty; (2) Just and civilized humanity; (3) Indonesian Unity; (4) Community-led by solemn wisdom in representative deliberations; and (5) Social justice for all Indonesian people. As the ideal of law and the source of all sources of law in Indonesia, Pancasila is a fundamental norm of the state or statutory norm, so the formation of law, its application, and implementation must be based on the values of Pancasila.

If we trace back, all the leadership eras that have been in power in Indonesia have stated and considered Pancasila as important and felt that they had implemented the values contained in Pancasila. However, history also records that the implementation of Pancasila which was considered "correct" at that time was deviant because it was not following what it should have been. So, there are leaders who feel they have implemented Pancasila but deviate from what they should be, there are also those who do not implement it and only make Pancasila just a slogan.

The reality is that the political orientation of Indonesian law is no longer thinking about how the rulers regulate life together, but how the rulers organize governance in such a way that they remain in power. Indonesian legal politics tend to think more about how power is maintained as long as possible rather than how Indonesia is best developed. This way of thinking is in line with Machiavelli's modern concept of politics.

The importance of Pancasila as the ideals of law and the source of all sources of law in Indonesia, because in this case, Pancasila has not yet fully become a directing star, a guide in implementing the formation of legislation as a legal product based on Pancasila values. Based on the above background, it is important to study the position of Pancasila as a legal ideal and the source of all sources of law in Indonesia. The reality of Pancasila as the ideal of law and the source of all sources of law in Indonesia is a necessity that must be realized in the development of Indonesian law.

\section{Research Problem}

According to the background which has been explained above, after the identification, then the research problem formulation is below:

How is the position of Pancasila as legal ideals and source of all legal sources in Indonesia?

\section{Research Method}

This research is a normative legal research. Juridic normative method is a library legal research which is performed by examining library materials or secondary data only [1]. The research is using historical approach philosophy approach. The legal material used are primary, secondary, and tertiary legal material.

\section{Results and Discussion}

Pancasila is the foundation of national and state life. As the foundation for the life of the nation and state, Pancasila has four positions, namely the state philosophy, ideology, legal ideals (rechtsidee), and the source of all sources of Indonesian law. In terms of legal ideals, philosophically the Preamble of the 1945 Constitution is a mode of Vivendi (noble agreement) for the Indonesian nation to live together in the bonds of one plural nation. The preamble to 
the 1945 Constitution can also be referred to as a certificate of birth, which contains a statement of independence (proclamation), self-identity, and steps to achieve the ideals of the nation and national goals. From a legal point of view, the Preamble to the 1945 Constitution which contains Pancasila is the basis of the state philosophy that gives birth to legal ideals (rechtsidee) and the basis for a separate legal system by the spirit of the Indonesian nation itself [2].

Thus, Pancasila is an agreement and consensus to build a nation and one country, without questioning differences in existing backgrounds, be it religion, race, ethnicity, culture, language, and others. As the basis of the state, Pancasila becomes rechtsidee (legal ideals) which must be stated in every lawmaking and enforcement.

According to Rudolf Stammler, the ideal of law (rechtsidee) serves as a determinant of the direction for achieving the ideals of society. Although it is fully realized that the final point of the ideals of society is not possible to fully achieve, the ideal of law provides positive benefits because it contains two sides, with the idea of law that the applicable positive law can be tested and to the ideals of law, it can be directed to positive law as an effort to regulate the life of the people of the nation and state. Justice that is intended as the ideal of law is also an effort and action to direct positive law towards legal ideals. Thus, just law is a law that is directed by the ideals of law to achieve the goals of society [3]. Then Gustav Radbruch emphasized that the ideal of law (rechtsidee) does not only function as a regulatory measure, which tests whether a positive law is fair or not, but also functions as a constitutive basis, namely that determines that without legal ideals, the law will lose its meaning as law [4].

According to B. Arief Sidharta, which combines the functions of legal ideals put forward by Rudolf Stammler and Gustav Radbruch, that legal ideals function as a general principle that serves as a guiding principle of critical norms (evaluation rules) and a motivating factor in law enforcement (formation, application, enforcement, and discovery) and legal behavior [5].

Every legal ideal (rechtsidee) always has 2 (two) types of elemental or substance content. First, the emotional-idiosyncratic elements whose rational limit is problematic [6]. The emotional-idiosyncratic element in a legal ideal (rechtsidee) occurs from the philosophy of life adhered to by a person or a society which guides the person concerned to believe in a certain value system and not another. Second, the idea of law also contains rational elements that allow a general legal meaning to be drawn up (Allgemeine rechtsbegriff) following the content of the rechtsidee concerned [7]. The rational element in the ideals of law (rechtsidee) arises from the intelligence which makes a person or a group of community members decide to choose and believe in certain values and not to other values under the community and the physical environment that surrounds it.

Both of these elements are contained in Pancasila as the legal ideals (rechtsidee) of the Indonesian nation. The emotional-ideal and rational elements in the ideals of Pancasila law are the starting point or basis for the development and development of the Indonesian legal system and legal knowledge. In the context of the two elements of the ideals of law (rechtsidee) Pancasila, A.M.W. Pranarka argues that Pancasila is positioned as (a) a belief system and (b) a knowledge system [8].

Under the field of law, the manifestation of the ideology of Pancasila is rendered into the ideals of Pancasila statutes which serves as the foundation and direction of the development and expansion of national law. The ideals of Pancasila law are interpreted as rules of community behavior that are rooted in notions, feelings, intentions, creations, and opinions of the community itself. In this case, there are three elements, specifically justice, usability, and legal certainty [9]. 
The ideals of Pancasila law are based on the view of the life of the Indonesian nation which believes that the universe and everything in it, including humans and nature as a whole are interwoven in a harmonious relationship created by God. The presence of humans in the world is hallowed in being with each other, but no human has a unique personality that distinguishes one from another. This is where there is unity indifference. Besides, togetherness (unity) shows a different and unique nature of personality, which means that there is diversity in unity. The nature of this difference cannot be denied without involving a degree of humanity, which can be manifested in life in society [10].

Pancasila as a legitimate model contains ideal values to be implemented in the life of the Indonesian society. These ideal values become the starting point in developing and advancing the Indonesian legal system. The ideals of Pancasila law can be understood as a frame of thought that leads the law to the ideals sought by the Indonesian people. Attamimi stated that Pancasila as a legal ideal (rechtsidee) will consistently and continuously perform its two functions which are constitutive and regulative towards the Indonesian legal norm system. As a legal ideal (rechtsidee), Pancasila has three values, namely [11]:

a. Basic values, namely the principles that are accepted as propositions that are more or less absolute. The basic values of Pancasila are divinity, humanity, unity, democratic values , and justice values.

b. Instrumental value, namely the general implementation of basic values, especially the formation of legal norms which are then crystallized in statutory regulations.

c. Practical values, namely values that are implemented in reality, appear from basic values and instrumental values so that the real practical value becomes the examination stone whether the basic values and instrumental values live in Indonesian society. For example, community docility with the law or law enforcement.

The three values mentioned above are then explicated into legal norms. The realization of these three values is significant because the law that is to be established must be able to integrate and harmonize Indonesia's national interests at national, regional, and global levels, so that based on the values of Pancasila as a guiding star to test and give direction to positive law in Indonesia [12].

By making it a guiding star or guide to positive law in Indonesia, it has made Pancasila the source of all sources of law in Indonesia. In such a position, the Preamble of the 1945 Constitution and Pancasila which are contained into fundamental norms or principles of state principles are fundamental and cannot be changed utilizing law, unless changes are made to the Indonesian identity that was born in 1945.

The arrangement of Pancasila as a staatfundamentalnorm was originally conveyed by Notonagoro [13]. Pancasila is perceived as the ideal of law (rechtsidee) as a guiding star of law formation and law enforcement. This position requires that the formation of positive law is to achieve the ideas in Pancasila, and can be used to examine positive law. With the stipulation of Pancasila as the statutory norm, the formation of law, application, and implementation cannot be separated from the values of Pancasila [14]. As a consequence, Pancasila is placed as a fundamental norm in the legal norm system which determines that the legal norms under it are formed by and not contradicting Pancasila [15].

The affirmation that Pancasila is a source of law has been legitimized by several provisions of the MPRS Decree No. XX / MPRS / 1966 (in conjunction with the MPR Decree No. V / MPR / 1973, in conjunction with the MPR Decree No. IX / MPR / 1978) concerning the DPRGR Memorandum regarding the Sources of Order of Law of the Republic of Indonesia and the Order of RI Legislation and MPR Decree No.III / MPR / 2000 concerning Legal Sources and the Order of Legislation. In the reformation era, Pancasila was reaffirmed by Law Number 10 
of 2004 which was later revised again by Law Number 12 of 2011 concerning the Formation of Laws and Regulations.

Law Number 12 of 2011 concerning the Formation of Legislative Regulations, Article 2 states that Pancasila is the source of all sources of state law. In line with what was stated by Kirdi Dipoyudo, that as the basis of the state Pancasila is the source of state order and legal order, supreme power, the soul of the 1945 Constitution, and guidelines for interpreting it and for implementing it in statutory regulations [16].

Despite the position of Pancasila as the source of all sources of law in Indonesia, it is hoped that a national legal system can be created which (1) can guarantee the integration of the nation and state both ideologically and territorially; (2) based on the people's agreement, whether it is decided through deliberation to reach a consensus or by voting, and the results can be tested for juridical consistency with rechtsidee; (3) can achieve general welfare and social justice; (4) can realize civilized religious tolerance, in the sense of not allowing or discriminating against certain groups or groups [17].

The aforementioned rights are following Law Number 12 of 2011 concerning the Formation of Legislative Regulations, which states that the formation of national law needs to be based on the principles of protection, humanity, nationality, kinship, nationality, diversity in unity, justice, equality in law and governance, order and legal certainty, balance, harmony, and harmony [18]. The principles of establishing this statutory regulation are a derivation of the noble values of Pancasila as a legal ideal (rechtsidee). Thus, Pancasila becomes the spirit and spirit that animates the formation of national law.

Discussing about the order in the hierarchy of legal norms presented by Nawiasky, Nawiasky divides it into 4 (four) hierarchical laws, namely [19]:

a. Staatsfundamentalnorm in the form of basic state norm and source of all legal sources;

b. Staatsgrundgezetze which is in the form of basic law which, if set forth in a state document, becomes a constitution or vervassung;

c. Formelegezetze or a formal law which in said regulation an imperative provision, in the sense of implementation or legal sanction;

d. Verordnung en and autonome satzungen, namely, autonomous implementation and regulation, both born of delegation and attribution.

By standing on Nawiasky's theory, it is increasingly obvious that Pancasila in the practice of the Indonesian state legal system obtains a position as the Staatsfundamentalnorm, or in his Stufen theory, Hans Kelsen uses the term grundnorm for the highest hierarchy of laws and regulations.

According to Jimly Asshiddiqie, the term staatsfundamentalnorm is used by Nawiasky to distinguish between the meaning of the constitution. According to him, not all of the values contained in the constitution or the UUD constitute statutory norms. Values that are included in fundamental norms/staatsfundamentalnorm according to him are only as of the strength of the values contained in the constitution, while the norms written in articles of the constitution are categorized as abstract norms. Therefore, if it is related to the constitutional system of the Republic of Indonesia, it can be distinguished between the Preamble of the 1945 Constitution (which includes Pancasila) and the Articles of the 1945 Constitution of the Republic of Indonesia [20].

According to Bernard L. Tanya, Pancasila as the fundamental norm is used as a guide in the preparation of the Indonesian legal system. Concerning law, these eight frames serve as basic norms that provide a moral-ethical foundation [21].

The first frame is to care for Indonesians, to give a mission to law, Indonesian law has the main embassy, namely to make Indonesia a "home for all its (plural) inhabitants to live 
peacefully in it". The second frame of Pancasila provides the basis for an ethos of legal methods, namely a social ethos that elevates honesty, knighthood, the courage to be responsible, obeying principles, never breaking promises, siding with the truth, upholding justice, obeying, and being loyal to the rules of the game together.

Then the third frame, (lebensphilosophie), provides an existential context for Indonesian law. Indonesian law is the law for living together in an Indonesian home. This community life is a life based on cooperation to create goodness.

The fourth frame, the spirit of accomplishing everything right, just, and good as the essence of the Divine precepts, provides a moral-ethical foundation for Indonesian law. Law enforcement at all levels must start from the spirit to do what is right, just, and good. The fifth frame, the need to care for human values, justice, and civility, provides a normative basis for Indonesian law. The sixth frame is the necessity to maintain national integration, to provide a national foundation in Indonesian law to prioritize the interests of national unity over the narrow primordial loyalties of a group or society.

The seventh frame is the necessity to care for the people/democracy that is wise and wise, providing a mass foundation for the law. The law must be pro-people. The eighth frame is the necessity to care for social justice in social life. The values and noble spirit in those eight frames can be seen as the strengths of Pancasila compared to Hans Kelsen's grundnorm [22].

\section{Conclusion and Suggestion}

\subsection{Conclusion}

Pancasila is the foundation of national and state life. As the grounds for the life of the nation and state, Pancasila has four positions, namely the state philosophy, ideology, legal ideals (rechtsidee), and the source of all sources of Indonesian law. The position of Pancasila as a legal ideal (rechtsidee) and the source of all sources of Indonesian law has not been entirely utilized in the implementation of the formation of legislation as intended by the founders of the state. As a result, several laws and regulations were judged to be reexamined by the Constitutional Court considering to be contradicting Pancasila values. This is due to the lack of understanding of Pancasila as the ideal of Indonesian law. Likewise, Pancasila as the source of all sources of law, the legislators do not have implementation instructions and technical instructions that can be practiced when interpreting the principles of Pancasila into legal norms of all laws and regulations, so that in practice rendering according to their respective interpretations. By stipulating Pancasila as a fundamental norm (staatsfundamentalnorm), the formation of law, application, and implementation cannot be separated from the values of Pancasila.

\subsection{Suggestion}

It is hoped that lawmakers in Indonesia can return to the nation's philosophy by making Pancasila a guiding star that provides guidance and leadership in all legislative activities, provides the content to each statutory regulation, as well as a framework that limits the space for the contents of the legislation. Pancasila as a dynamic ideology can indeed develop according to the context of its era, but its basic philosophy must be consistent with the intent of the founders of the state. 
Therefore there is a need for awareness of the ideals of Pancasila law and making Pancasila the source of all sources of law in Indonesia, especially in state administrators and people's representatives in the DPR who have an interest in the formation of laws and regulations. As a Pancasila legal state, the ideals of Pancasila law must be placed as the basis and direction for the formation of legislation in Indonesia. Likewise, Pancasila must be the source of all sources of law in Indonesia.

\section{References}

[1] Soekanto, Soerjono dan Sri Mahmudji.: Penelitian Hukum Normatif, Suatu Tinjauan Singkat. Raja Grafindo Persada, Jakarta (2003).

[2] [17] Hidayat, Arief.: Negara Hukum Berwatak Pancasila. Artikel. Retrieved from https://mkri.id/public/content/infoumum/artikel/pdf/artikel_15_03_arief_hidayat.pdf

[3] Saleh, Roeslan.: Pembinaan Cita Hukum dan Penerapan Asas-asas Hukum Nasional. Majalah Hukum Nasional (Edisi Khusus 50 Tahun Pembangunan Nasional), No. 1. Pusat Dokumentasi Hukum BPHN Departemen Kehakiman, Jakarta (1995).

[4] Sisworo, Soejono Koesoemo.: Mempertimbangkan Beberapa Pokok Pikiran Pelbagai Aliran Filsafat Hukum Dalam Relasi dan Relevansinya Dengan Pembangunan/Pembinaan Hukum Indonesia. Kumpulan Pidato Pengukuhan Guru Besar Fakultas Hukum Universitas Diponegoro Semarang dihimpun oleh Soekotjo Hardiwinoto, Badan Penerbit Universitas Diponegoro, Semarang (1995).

[5] Sidharta, B. Arief: Refleksi Tentang Struktur Ilmu Hukum. Mandar Maju, Bandung (2000).

[6] Koesnoe, Moh.: Perumusan dan Pembinaan Cita Hukum dan Asas-Asas Hukum Nasional, Ditinjau dari Hukum Adat. Varia Peradilan, Nomor 120, Jakarta (September 1995).

[7] Koesnoe, Moh.: Perumusan dan Pembinaan Cita Hukum dan Asas-Asas Hukum Nasional, Ditinjau dari Hukum Adat. Varia Peradilan, Nomor 120, Jakarta (September 1995).

[8] Pranarka, A.M.W., Suatu Konstruksi Filsafat Hukum Dengan Latar Belakang Evolusi Pengetahuan Dewasa Ini. Jurnal Pro Justitia, Fakultas Hukum Universitas Parahyangan, Bandung (1992).

[9] [10] Sidharta, Bernard Arief.: Refleksi Tentang Fundadi dan Sifat Keilmuan Ilmu Hukum sebagai Landasan Pengembangan Ilmu Hukum Nasional Indonesia. Disertasi. Fakultas Hukum Universitas Padjajaran, Bandung (1996).

[11] Prasetyo, Teguh dan Arie Purnomosidi.: Membangun Hukum Pancasila. Nusa Media, Bandung (2014).

[12] Prasetyo, Teguh dan Arie Purnomosidi.: Membangun Hukum Pancasila. Nusa Media, Bandung (2014).

[13] Notonagoro.: Pembukaan Undang-Undang Dasar 1945 (Pokok Kaidah Fundamental Negara Indonesia) dalam Pancasila Dasar Falsafah Negara. Cet. 7, Bina Aksara, Jakarta (1988).

[14] Attamimi, A. Hamid. S.: Peranan Keputusan Presiden Republik Indonesia Dalam Menyelenggarakan Pemerintahan Negara, Suatu Studi Analisis Mengenai Keputusan Presiden Yang Berfungsi Pengaturan Dalam Kurun Waktu Pelita I- Pelita IV. Disertasi, Program Doktor Fakultas Pasca Sarjana. Universitas Indonesia, Jakarta (1990). 
[15] Kaelan.: Negara Kebangsaan Pancasila; Kultural, Historis, Filosofis, Yuridis, dan Aktualisasinya. Paradigma, Yogyakarta (2013).

[16] Dipoyudo, Kirdi.: Pancasila, Arti dan Pelaksanaannya. CSIS, Jakarta (1984).

[18] Undang-Undang Republik Indonesia Nomor 12 Tahun 2011 tentang Pembentukan Peraturan Perundang-Undangan.

[19] Darmodihardjo, Dardji.: Pokok-pokok Filsafat Hukum, Apa dan Bagaimana Filsafat Hukum Indonesia. Gramedia, Jakarta (1999).

[20] Assihiddiqie, Jimly.: Pengantar Ilmu Tata Negara. Sekretariat Jenderal dan Kesekretariatan Mahkamah Konstitusi RI, Jakarta (2006)

[21] Tanya, Bernard L, Theodorus Yosep Parera, \& Samuel F. Lena: Pancasila Bingkai Hukum Indonesia. Genta Publishing, Yogyakarta (2015).

[22] Tanya, Bernard L, Theodorus Yosep Parera, \& Samuel F. Lena: Pancasila Bingkai Hukum Indonesia. Genta Publishing, Yogyakarta (2015). 